\title{
Environmental Component Economic Evaluation of the Renewable Energy Sources Life Cycle
}

\author{
$E N$ Sosnina $^{1}, O V$ Masleeva $^{1}, E V$ Kryukov $^{1, *}$, and $N I$ Erdili $^{1}$ \\ ${ }^{1}$ Nizhny Novgorod State Technical University n.a. R.E. Alekseev, 24 Minin St., Nizhny Novgorod, 603950, Russia
}

\begin{abstract}
Traditionally, renewable energy sources (RES) are considered the most environmentally friendly, but only the stage of their operation is evaluated. A method for the integrated assessment of the renewable energy environment sustainability has been proposed, taking into account their entire life cycle from the extraction of natural resources for the production of a power plant to its utilization. An impact assessment of RES different types on the environment has been carried out in four areas: consumption of natural resources, pollution of water resources, pollution of the soil and pollution of the atmosphere. The comparison of the considered environmental components has been carried out on the basis of an environmental pollution economic assessment at the stages of the RES life cycle. Studies have shown that the life cycle of a solar power plant makes the greatest contribution to environmental pollution, but the mini-hydroelectric station - the smallest.
\end{abstract}

\section{Introduction}

The concept of the steady human development includes environmental sustainability, economic viability and social acceptability. Environmentally steady development ensures the preservation of raw materials sources and the environment as a place of pollution flow, at which the level of emissions should not exceed the assimilation capacity of nature.

Therefore, one of the main strategic guidelines of the long-term state energy policy in the Concept of the "Energy Strategy of Russia for the Period until 2030" is the environmental safety of the energy sector. For its implementation energy-efficient and resource-saving technologies based on renewable energy sources (RES) and cogeneration-based sources are being introduced [2]. The development of non-fuel energy will reduce the burden on the environment and stabilize the production of fossil fuels.

Among all RES, wind and solar power plants, as well as mini-hydroelectric power stations, are the most common. The impact of renewable energy on the environment during their operation is believed to be negligible [3].

During the operation of wind turbines, the main harmful environmental effects are increased noise and vibration, large areas of wind farms, changes in the landscape, and the impact on flora and fauna. The operation of solar stations is the most environmentally friendly. The main disadvantage of solar energy is large areas required for the placement of solar cells $[4,5]$. The environmental advantages of using mini hydropower plants include: smaller areas of flooding or their absence; a lesser degree of disturbance to the normal natural habitat of humans, wildlife and fisheries; the use of water resources from reservoirs has a positive effect on the rivers in dry areas.

Using RES, on the one hand, allows solving a whole range of problems related to environmental management, more comfortable working and living conditions for the people, ecology, and the economies of the regions and the country as a whole. On the other hand, at present, the damage to the environment caused in the process of making RES has not been fully estimated. The data available in the literature have been obtained by different authors in evaluating installations of different power and conditions for the location and operation, which makes it impossible to carry out an adequate comparative assessment.

In this paper, the authors have set the task to analyze the environmental component of the life cycle of RES, as well as carry out its economic assessment.

\section{Methods}

The authors have developed a methodology for assessing the life cycle of RES [6]. The life cycle of RES includes the stages of mining, the subsequent production of materials and the manufacture of the installation, operation and disposal at the end of its use [7, 8].

As an example, the following types of power installations (PI) on RES with a capacity of $30 \mathrm{~kW}$ have been considered: wind power installation (WPI) «Musson»; solar power installation (SPI) Saana 250 LM3 MBW (120 modules); mini-HPP INSET Pr 30.

The initial data for the inventory analysis of the system are the materials necessary for the production of the PI on RES functional units: WPI - generator (steel,

\footnotetext{
* Corresponding author: kryukov@nntu.ru
} 
copper), blades (plastic), support (steel); SPI - solar module (silicon), body (aluminum, glass), support (steel); mini-HPP - generator (steel, copper), hydro turbine (steel), housing (steel).

The masses of materials are determined by technical data and are given in table 1 .

Table 1. Inventory analysis of PI on RES results.

\begin{tabular}{|c|c|c|c|}
\hline \multirow{2}{*}{ Material } & \multicolumn{3}{|c|}{ Mass of PI materials, kg } \\
\cline { 2 - 4 } & WPI & SPI & Mini-HPP \\
\hline Steel & 3056 & 6000 & 1962 \\
\hline Copper & 38 & - & 38 \\
\hline Aluminum & - & 276 & - \\
\hline Glass & - & 1920 & - \\
\hline Silicon & - & 340 & - \\
\hline Plastic & 100 & - & - \\
\hline Total & 3184 & 8536 & 2000 \\
\hline
\end{tabular}

The RES life cycle consists of the following stages: minerals mining (iron, copper ore, bauxite, gas); materials production (steel, copper, silicon, glass, plastics); energy sources production; recycling process (steel, copper, glass, plastics).

Environmental impact assessment is conducted in the following areas: natural resources consumption (minerals, water); water resources pollution; soil pollution; air pollution.

The comparison of environmental components is carried out using the economic assessment of environmental pollution at the life cycle stages.

\section{Life Cycle Assessment of renewable energy sources}

\subsection{Land Exclusion}

In the construction of power plants, the land is being alienated, the area of which depends on the type and capacity of the station.

According to [9] the width of the sanitary protection zone is set with account of the results in expected air pollution calculations and levels of physical effects. The territory of the sanitary protection zone is designed to ensure that the level of exposure is reduced to the required hygienic standards for all exposure factors outside of it.

For SPI and mini-HPP, a sanitary protection zone is not required. For WPI, the main criterion is acoustic pollution. The boundaries of sanitary protection zones must be at least $50 \mathrm{~m}$ from the source, if an acoustic calculation does not require an adjustment in the direction of its increase [10]. The results of the analysis of RES specific areas and the size of the sanitary protection zone are given in table 2 .

Table 2. Results analysis of the RES specific areas and the size of the sanitary protection zone.

\begin{tabular}{|c|c|c|}
\hline RES type & Square, $\mathbf{~ m}^{\mathbf{2}}$ & Sanitary area size, $\mathbf{m}$ \\
\hline PI & 6000 & 50 \\
\hline SPI & 300 & 0 \\
\hline Mini-HPP & 0 & 0 \\
\hline
\end{tabular}

The economic assessment of the land alienation has not been carried out, since it has been assumed that the RES are located on its own territory, and an additional fee is not required.

\subsection{Natural resources}

The consumption calculation of natural resources (iron, copper ore, bauxite, natural gas, sand, quartzite) is given in [6] based on the mass of materials used to produce PI, and the specific values of waste generation at all stages of the life cycle. The calculation results are shown in table 3. The economic assessment of the natural resources consumption has not been carried out due to the limited source data in the open press.

Table 3. Results of calculating the natural resources consumption.

\begin{tabular}{|c|c|c|c|}
\hline \multirow{2}{*}{$\begin{array}{c}\text { PI } \\
\text { type }\end{array}$} & \multirow{2}{*}{ Component } & \multicolumn{2}{|c|}{ Mining, t } \\
\cline { 3 - 3 } & & Component mass & Total mass \\
\hline \multirow{3}{*}{ WPI } & steel & 13.900 & \multirow{2}{*}{17.1} \\
\cline { 2 - 3 } & copper & 3.064 & \\
\cline { 2 - 3 } & plastic & 0.102 & \multirow{2}{*}{40.2} \\
\hline \multirow{3}{*}{ SPI } & steel & 27.200 & \\
& glass & 4.992 & \\
\cline { 2 - 3 } & silicon & 0.874 & \multirow{2}{*}{12.0} \\
\cline { 2 - 3 } & aluminum & 7.121 & \\
\hline Mini- & steel & 8.900 & \\
\cline { 2 - 3 } HPP & copper & 3.064 & \\
\hline
\end{tabular}

\subsection{Water resources}

The water consumption calculation [6] for the PI

Table 4. The calculation results of water consumption and its economic evaluation.

\begin{tabular}{|c|c|c|c|c|}
\hline \multirow{2}{*}{ PI type } & \multicolumn{4}{|c|}{ Life cycle stage } \\
\cline { 2 - 5 } & Total & Mining & Production & Recycling \\
\hline \multicolumn{5}{|c|}{ Water consumption, m $\mathbf{~ 3}^{\mathbf{3}}$} \\
\hline WPI & 362 & 49 & 269 & 43 \\
\hline SPI & 999 & 86 & 828 & 28 \\
\hline Mini-HPP & 233 & 35 & 170 & 381 \\
\hline EPI & 3679 & 582 & 2715 & 754 \\
\hline SPI & 11878 & 1145 & 9980 & 245 \\
\hline
\end{tabular}


Table 5. The calculation results of water disposal, the water disposal economic assessment and the discharge of harmful substances with wastewater.

\begin{tabular}{|c|c|c|c|c|}
\hline \multirow{2}{*}{ PI type } & \multicolumn{5}{|c|}{ Life cycle stage } \\
\cline { 2 - 5 } & Total & Mining & Production & Recycling \\
\hline \multicolumn{5}{|c|}{ Water disposal, m } \\
\hline WPI & 77 & 3 & 57 & 17 \\
\hline SPI & 342 & 9 & 300 & 33 \\
\hline Mini-HPP & 49 & 2 & 36 & 11 \\
\hline \multicolumn{5}{|c|}{ Economic assessment of water disposal, rub. } \\
\hline WPI & 1254 & 50 & 901 & 302 \\
\hline SPI & 6580 & 154 & 5826 & 601 \\
\hline Mini-HPP & 792 & 32 & 566 & 194 \\
\hline Economic assessment of discharge of hazardous substances with wastewater, rub. \\
\hline WPI & 327 & 102 & 224 & 1.0 \\
\hline SPI & 529 & 8.3 & 518 & 2.0 \\
\hline Mini-HPP & 253 & 101 & 152 & 0.6 \\
\hline
\end{tabular}

production has been made according to the specific water consumption norms $(\mathrm{m} 3 / \mathrm{t})$ for technological operations at the stages of the life cycle [11] and is given in the table 4.

The water consumption economic assessment has been made on the basis of tariffs for water consumption for 2018 in the regions where the enterprises are located - the sources of water consumption in mining, production and its disposal (table 4).

The water disposal rate $(\mathrm{m} 3 / \mathrm{t})$ is determined by the water consumption rate and water losses in the process of its use in accordance with the production water supply scheme, with the account of the expediency of extracting valuable impurities and a necessary degree of wastewater treatment from pollution [11]. The results of the calculation of wastewater are given in table 5 .

The economic assessment of water disposal has been made on the basis of tariffs for water disposal in 2018 by the regions where there are enterprises for the extraction of minerals, its production and disposal (table 5).

The economic assessment of the discharge of pollutants with wastewater (table 5) was carried out on the basis of the qualitative and quantitative composition of the pollutants in the wastewater of the respective enterprises in 2018 [12].

\subsection{Waste formation}

The calculation of the waste mass generated in the life cycle stages has been carried out in $[6,12]$. When calculating, it was taken into account that about $50 \%$ of the generated waste is utilized according to statistical data (table 6).

The economic assessment of waste disposal (table 6) was made on the basis of the waste mass generated, their hazard class for the environment, the coefficient with the account of the ecological state of the soil in the economic regions of the Russian Federation and the rate of waste disposal payment [13].

\subsection{Atmospheric air}

The qualitative and quantitative composition of pollutants with the enterprises at different stages of the life cycle emitted into the atmospheric air has been determined from reference books.

The economic assessment of pollutant emissions into the air has been performed on the basis of the harmful substances concentrations in the emissions and the coefficient considering the ecological state of atmospheric air in the territories of the Russian Federation economic regions, the rate of payment for emissions of pollutants into the atmospheric air [13] (table 7).

The calculation of greenhouse gas emissions has been performed in [14]. Russia currently does not have greenhouse gas emissions tariffs; therefore, it is not possible to make an economic assessment of this component [15].

Table 6. The results of calculating the mass of waste generated and the economic assessment of waste disposal.

\begin{tabular}{|c|c|c|c|c|}
\hline \multirow{2}{*}{ PI type } & \multicolumn{4}{|c|}{ Life cycle stage } \\
\cline { 2 - 5 } & Total & Mining & Production & Recycling \\
\hline \multicolumn{5}{|c|}{ Waste mass, t } \\
\hline WPI & 12.2 & 9.8 & 2.0 & 0.4 \\
\hline SPI & 28.6 & 23.1 & 4.7 & 0.8 \\
\hline Mini-HPP & 9.1 & 7.3 & 1.3 & 0.5 \\
\hline \multicolumn{5}{|c|}{ Economic assessment of waste disposal, rub. } \\
\hline WPI & 2224 & 21 & 1814 & 389 \\
\hline SPI & 4918 & 42 & 4095 & 781 \\
\hline Mini-HPP & 1501 & 13,2 & 1237 & 251 \\
\hline
\end{tabular}


Table 7. The economic estimate calculation results of pollutant emissions into the air.

\begin{tabular}{|c|c|c|c|c|}
\hline \multirow{2}{*}{ PI type } & \multicolumn{4}{c|}{ Life cycle stage } \\
\cline { 2 - 5 } & Total & Mining & Production & Recycling \\
\hline \multicolumn{5}{|c|}{ Economic assessment of pollutant emissions, rub. } \\
\hline WPI & 2.98 & 0.12 & 2.51 & 0.35 \\
\hline SPI & 7.90 & 0.25 & 6.35 & 1.30 \\
\hline Mini-HPP & 2.08 & 0.07 & 1.75 & 0.26 \\
\hline
\end{tabular}

Table 8. Total results of the economic assessment of environmental pollution.

\begin{tabular}{|c|c|c|c|c|c|c|}
\hline \multirow{2}{*}{ PI type } & \multicolumn{6}{|c|}{ Environmental assessment direction } \\
\cline { 2 - 7 } & $\begin{array}{c}\text { Waste } \\
\text { disposal }\end{array}$ & $\begin{array}{c}\text { Water } \\
\text { consumption }\end{array}$ & $\begin{array}{c}\text { Water } \\
\text { disposal }\end{array}$ & $\begin{array}{c}\text { Discharge of hazardous } \\
\text { substances with } \\
\text { wastewater }\end{array}$ & $\begin{array}{c}\text { Air emissions } \\
\text { of pollutants }\end{array}$ & Total \\
\hline WPI & 2224 & 3679 & 1254 & 327 & 2.98 & 7486 \\
\hline SPI & 4918 & 11878 & 6580 & 529 & 7.90 & 23913 \\
\hline Mini-HPP & 1501 & 2310 & 792 & 253 & 2.08 & 4859 \\
\hline
\end{tabular}

\section{Results and Discussion}

The overall results of the economic assessment of the environmental component of the RES life cycle are presented in the table 8 and on figure 1 .

The analysis of the results shows that the highest payment for environmental pollution during the life cycle falls on SPI, and the lowest - on Mini-HPP.

The greatest contribution to the total assessment is made by water consumption and disposal, as well as waste disposal.

The significant amounts of payment for environmental pollution confirm the need to account them in the environmental assessment of the choice of electricity source.

\section{Conclusion}

The proposed approach to the environmental assessment of RES provides an opportunity to most fully explore their environmental impact at all stages of the life cycle: from mining to disposal. The technique is universal and allows making the analysis, regardless of the type of PI considered.

The economic assessment of environmental pollution in the stages of the life cycle allows making a comparison of all environmental components.

The comparison of the results of the economic assessment has enabled to determine that the life cycle of a SPI is making the greatest contribution to environmental pollution, and the life cycle of a MiniHPP is doing the least harm.

The work has been carried out with the financial support of the Ministry of Science and Higher Education of the Russian Federation (state task №13.2078.2017/4.6 on May 31, 2017).

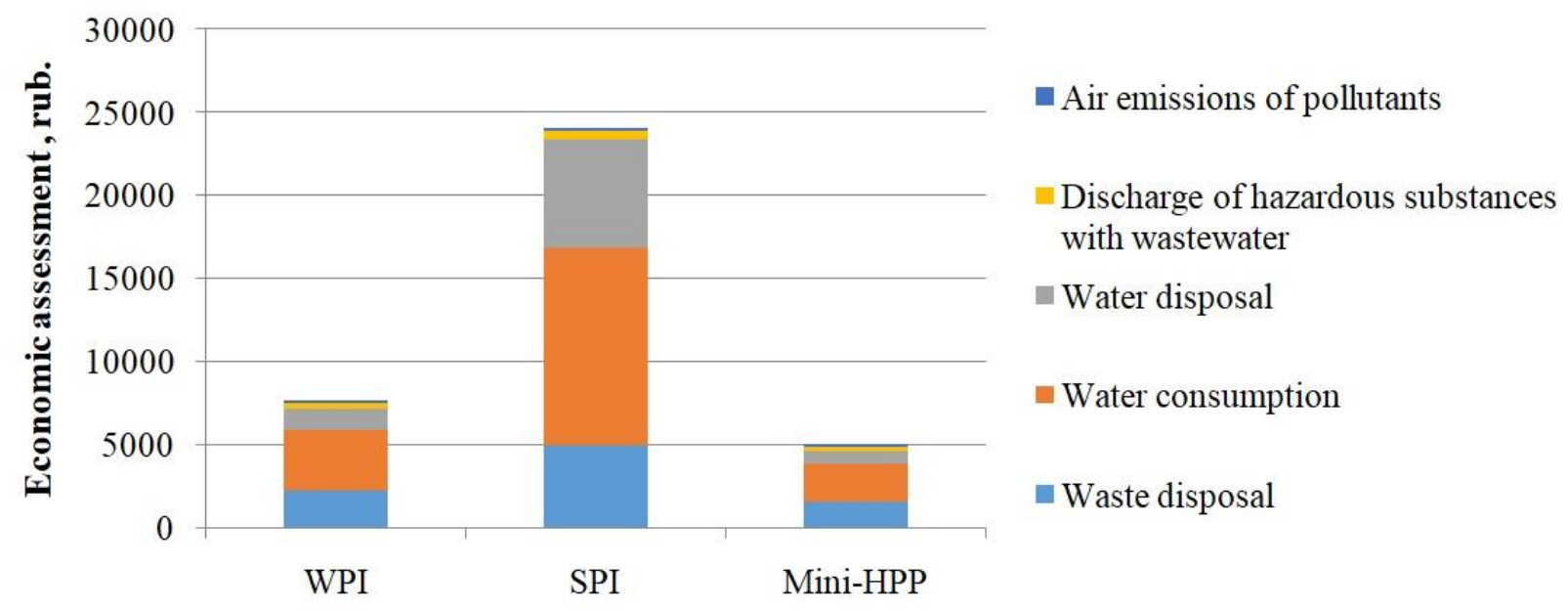

Fig. 1. Total results of the environmental component economic evaluation of the RES life cycle. 


\section{References}

[1] E. Loiseau, L. Saikku, R. Antikainen, N. Droste, B. Hansjürgens, K. Pitkänen, P. Leskinen, P. Kuikman, M. Thomsen, Journal of Cleaner Production, 139, 361-371 (2016).

[2] M.J. Burke, J.C. Stephens, Energy Research \& Social Science, 35, 78-93 (2018).

[3] N.L. Panwar, S.C. Kaushik, S. Kothari, Renewable and Sustainable Energy Reviews, 15, 3, 1513-1524 (2011).

[4] N.A. Ludin, N.I. Mustafa, M.M. Hanafiah, M.A. Ibrahim, M.A. Teridi, S. Sepeai, A. Zaharim, K. Sopian, Renewable and Sustainable Energy Reviews, 96, 11-28 (2018).

[5] S. Gerbinet, S. Belboom, A. Leonard, Renewable and Sustainable Energy Reviews, 38, 747-753 (2014).

[6] E. Sosnina, O. Masleeva, E. Kryukov, Thermal Engineering, 62, 8, 539-546 (2015).

[7] F. Asdrubali, G. Baldinelli, F. D'Alessandro, F. Scrucca, Renewable and Sustainable Energy Review, 42, 1113-1122 (2015).

[8] V. Campos-Guzmán, M.S. García-Cáscales, N. Espinosa, A. Urbina, Renewable and Sustainable Energy Reviews, 104, 343-366 (2019).

[9] SanRaR 2.2.1 / 2.1.1.1200-03, Sanitary protection zones and sanitary classification of enterprises, structures and other objects.

[10] STO 70238424.27.100.059-2009, Wind power plants (WPP), Terms of creation, Standards and requirements.

[11] Integrated water consumption and disposal standards for various industries, Moscow: Stroyizdat, 590 (1978).

[12] Sourcebook of specific indicators of the formation of production and consumption wastes (1999).

[13] Resolution of the Government of the Russian Federation, no. 913 "On the rates of payment for the negative impact on the environment and additional coefficients" (2016).

[14] E. Sosnina, O. Masleeva, G. Pachurin, E. Kryukov, Basic research, 11, 4, 709-714 (2015).

[15] N.Y. Amponsah, M. Troldborg, B. Kington, I. Aalders, R.L. Hough, Renewable and Sustainable Energy Reviews, 39, 461-475 (2014). 